\title{
Serine/Threonine-Protein Kinase Chk2
}

National Cancer Institute

\section{Source}

National Cancer Institute. Serine/Threonine-Protein Kinase Chk2. NCI Thesaurus. Code C40966.

Serine/threonine-protein kinase Chk2 (543 aa, $\sim 61 \mathrm{kDa}$ ) is encoded by the human CHEK2 gene. This protein plays an essential role in the DNA damage checkpoint of the cell cycle. 